\title{
Contracting arrangements and public private partnerships for sustainable development
}

EHTISHAM AHMAD, Ph.D.* ANNALISA VINELLA, Ph.D.*

KEZHOU XIAO, Ph.D. candidate*

\section{Article**}

JEL: D82, D86, H41, H61, O5

https://doi.org/10.3326.pse.42.2.8

\footnotetext{
* This paper was prepared at the request of the G24 Secretariat, and is being published with their permission. We are grateful to participants at a G24 Seminar in Addis Ababa in February 2017, and to Marilou Uy and Aldo Caliari for very helpful comments. The authors would also like to thank two anonymous referees for useful comments and suggestions. All errors are ours.

${ }^{* *}$ Received: November 13,2017

Accepted: February 15, 2018
}

A previous version of this paper was presented at the conference "Public Sector Economics 2017 - Public investment: catalyst for sustainable growth" organized by the Institute of Public Finance and Friedrich-EbertStiftung in Zagreb on November 3, 2017.

\section{Ehtisham AHMAD}

London School of Economics and Political Science, Houghton Street, London WC2A 2AE, UK Zhejiang University, 866 Yuhangtang Road, Hangzhou, Zhejiang Province, 310058, P. R. China e-mail: s.e.ahmad@1se.ac.uk

ORCiD: 0000-0002-6054-3336

\section{Annalisa VINELLA}

University of Bari “Aldo Moro", Largo Abbazia Santa Scolastica 53, 70124 Bari, Italy e-mail: annalisa.vinella@uniba.it

ORCiD: 0000-0002-2602-3089

Kezhou XIAO

London School of Economics and Political Science, Houghton Street, London WC2A 2AE, UK e-mail: K.Xiao@1se.ac.uk ORCiD: 0000-0002-1687-9043 
This paper extends the discussion of the investment cycle in Ahmad (2017) (G24 paper), in which the questions concerning "what" to invest in and "where" are addressed. This paper examines the "how" of investment for sustainable development, focusing on options for contracting arrangements, such as PPPs, that would help to involve the private sector, manage risks in the presence of asymmetric information, as well as uncertainty about climate change. It also addresses the strengthening of national and local institutions and the possible role of international financial institutions. In discussing the investment options, the paper also updates a G24 review of the empirical and theoretical literature on involving the private sector involvement in public investments (Ahmad et al., 2018).

Keywords: financing infrastructure investments, contracts, sustainable development

\section{INTRODUCTION: SETTING THE STAGE FOR PRIVATE PARTICIPATION IN PUBLIC INVESTMENT}

Given the huge infrastructure gaps faced in advanced and developing countries alike, there is growing recognition that the private sector needs to be better involved in public investments for sustainable development, from financing instruments to direct participation with various risk-sharing arrangements (Bhattacharya et al., 2016). A 2015 G24 paper examined the case of public-private partnerships (PPPs), given the high expectations on the part of many governments, as well as bilateral and multilateral donors (Ahmad et al., 2018). In this paper, we review the additional empirical evidence on PPPs that has become available since the 2015 paper. We focus on a data register of private participation in public infrastructure (PPIs) established by the World Bank, and the large body of theoretical literature that has emerged recently on contracts, as well as the applicability of PPPs in the handling of the uncertainty that is a feature in particular of climate change. This paper is a continuation of a discussion of the investment cycle, in which the "what" and the "where" are addressed in companion G24 papers (Ahmad, 2017), and the "how" is taken up below.

Among both theorists and practitioners, two highly topical questions are: (1) whether public agencies, or private firms, or both in cooperation, should develop infrastructure projects; and (2) if so, under what organizational and contractual forms?

Private involvement in public infrastructure is subject to asymmetric information that triggers incentives for cost reduction through cuts in quality, unless quality is contractually well-defined, specified and monitored as argued in G24 (2015). In addition, PPPs create possibilities of game-play across levels of government, and incentives to hide liabilities at lower echelons. This often substitutes for tax reforms and obfuscates accountability as liabilities are pushed onto future generations or to higher levels of government. The reduced linkage between taxation and spending affects "yardstick competition", and can lead to a buildup of liabilities through poor decision-making. Elections are also often a trigger for reneging on contracts by both the public and private parties, giving rise to a host of political 
economy problems, especially pronounced in multilevel states (including those with unitary constitutions, but especially problematic in multiparty federal states). The importance of own-source taxes at lower levels of government to ensure sanctity of contracts, including for PPPs, is typically ignored by policymakers, although there are important exceptions (see Milbradt, 2016; Ahmad, Bordignon and Brosio, 2016).

The failure in the EU to implement requirements of the International Public Sector Accounting Standards Board (IPSAS) to register liabilities in general government balance sheets, also required under the IMF's Government Financial Statistics Manual (GFSM) 2014 framework, contributed to surprises and the depth of the post-2008 crisis. Therefore, contractual (in)completeness, on one hand, and monitoring and control, on the other, are critical issues in the choice of delegation of projects to the private sector. For instance, France, of the few EU countries to do so, has only recently begun to implement the IPSAS/GFSM requirements.

This paper is structured as follows. Section 2 focuses on some preconditions for PPPs. Section 3 presents some stylized facts on PPPs around the world. In Section 4 we examine a range of possible contracts, including the pros and cons of unbundling different stages of the project life-cycle. Section 5 concludes.

\section{SOME RECENT EVIDENCE ON PRECONDITIONS FOR PPPS}

After some "irrational exuberance" concerning PPPs in the international community and different countries, it was recognized that this enthusiasm was often due to the attractiveness of "kicking the fiscal can down the road", including in the EU (see below). McKinsey Global Institute (2016) had a more balanced perspective: "PPPs are often discussed as a solution but they are not a panacea." The main advantages of PPPs are bringing private capital into public infrastructure, through risk-sharing devices, in an innovative manner that helps to close the key infrastructure financing gaps. PPPs also help introduce greater efficiency and market discipline in the management and execution of the project than might in principle be possible in the public sector.

The typical critiques of PPPs are that (1) governments may use off balance-sheet investments to circumvent budget constraints; (2) windfall private-sector profits may accrue; (3) inappropriate risk transfer (with e.g., regulatory changes, land access, and traffic volumes) may increase capital costs; and (4) non-standard or insufficient project size may increase administrative costs (McKinsey Global Institute, 2016).

In addition to these criticisms, our focus is on whether and how asymmetric information generates first, political economy problems across levels of government, and second, game-playing between the public and private partners. The absence of appropriate incentives can also create commitment problems and incentives to renege on contracts (see G24, 2015). Separately, the new literature on climate change and uncertainty suggests that PPPs that focus on risk-sharing may not be the appropriate contracting model in every case. 
Despite these criticisms, the case for involving the private sector in public investment projects remains strong, including through the use of PPPs. We examine this issue further in section 4 .

\subsection{LOCAL OWN-SOURCE REVENUES}

There is clearly a potential for PPPs in meeting public infrastructure needs, although the preconditions need to be explicitly recognized. National governments and international agencies alike should try to assist lower levels of administration, particularly cities and municipalities, where many of the PPPs are typically to be found.

As discussed in Ahmad (2017), it may not be appropriate to set user charges to cover costs. There may well be implicit tax/subsidies or guarantees involved that affect budget allocations over the short to medium term. Problems typically arise when governments operating under an annual budget framework are unable to meet commitments under future budget scenarios. The problems tend to be magnified when elections result in new administrations that may have different priorities. Also, there is often a tendency for private parties to claim cost escalations prior to, or just after, elections. And if subnational governments are able to either hide costs (a practice common in some Latin American countries with single term limits, thereby enabling administrations to pass on the costs to their successors) or pass them on to higher levels of government, the incentives to renege on contracts are intensified.

A proper system of local own-source revenues is needed before cities can borrow for investment purposes in a sustainable manner. This linkage is important to align incentives. It is important also to recognize that PPPs represent local liabilities, and the repayment schedule needs to be linked to own-source revenue generation. Otherwise, there is a risk of liabilities building up unnoticed until there is a crisis, as was the case in Europe after 2008 (Ahmad, Bordignon and Brosio, 2016).

Unfortunately, international experience with raising revenues at city and local levels leaves much to be desired. Most developing countries generate negligible local revenues - Latin America, which perhaps does better than other regions, manages just $0.3 \%$ of GDP - as opposed to advanced countries such as the US, UK, and France that collect over 3\% of GDP at the local level. Part of the problem is that countries have adopted the US institutional model based on ownership and valuation, which is exceedingly difficult to administer (the UK under Margaret Thatcher abandoned it), given rapidly changing property rights and prices. Also, the administration of local-level taxes tends to be regarded as separate from other taxes, particularly the VAT and income taxes, and therefore is left to under-staffed and ill-equipped local administrations that rely on direct contact with taxpayers. This contributes to corruption and misses the important interlinkages of information on local assets as a key element in the income tax base. Yet, local-level taxation has significant potential, especially in rapidly growing cities and metropolitan areas within developing countries. The linkage between local own-source 
revenue generation and city-level investment and service delivery is critical to meeting the Sustainable Development Goals (SDGs). These issues are discussed in greater detail in Ahmad (2017a) and Ahmad, Brosio and Gerbrandy (2017), and are not pursued further here.

\subsection{FULL INFORMATION ON LIABILITIES GENERATED}

Without full information on the buildup of liabilities, known to the private partner but not the government, it is impossible to properly assign risks or manage the PPP process efficiently. Moreover, if the liabilities are not known to the local governments managing the PPP projects, they will be a black box to the central government that is responsible for overall macroeconomic management and implementation of fiscal rules at the national and sub-national levels. For these reasons, IPSAS 32 requires that PPP liabilities be recorded in the general government balance sheet, the latter being a critical element of the IMF's GFSM framework. The issue of accurate measurement and reporting of liabilities is increasingly important, given the emphasis on PPPs' meeting the UN's sustainable development goals (see Ahmad et al., 2018). For instance, this is now an important issue in China, which is basing its strategy for rebalancing growth toward sustainable and clean sources partly on PPP contracts.

One example of the importance of this precondition comes from the EU. The absence of consistent and full reporting on PPPs within countries and across the EU led to the failure of the practice of relying on the market to discipline local governments during the post-2008 economic crisis (see Ahmad, Brosio and Gerbrandy, 2016). Local governments could hide liabilities by, for instance, bypassing regular payment channels, dealing with local banks, and parking liabilities in PPPs. Additional and largely hidden liabilities have added to the magnitude of the crisis. In Spain, for example, there have been prosecutions of officials and banks, there are fears that funds have been misappropriated in several cases. It is unrealistic that markets would discipline local governments without full information on current and future payment streams, and without the need for standardized reporting of transactions and arrears (such as with the OECD/IMF GFSM standards).

How could the public sector ensure provision of full information on liabilities? It is common for countries to purchase expensive Integrated Financial Management Information Systems (IFMISs), often with IFI support, without thinking through how it might affect the processes and procedures across government entities or the architecture of connection between line agencies and sub-national governments. It is also common for line agencies or local governments to act independently of the Ministry of Finance or Treasury and purchase their own systems, often with charts of accounts that make it virtually impossible to generate data on general government operations - either the economic classification that would also cover the buildup of liabilities, or the functional or program classifications that make it possible to report on the key SDG deliverables, such as spending and outcomes on education or health care, for instance. 
Thus, for instance, countries such as Pakistan are only able to report on budgetary central government operations and not on the functional spending or outcomes necessary for their SDGs. These data have to be generated manually, and cannot easily be verified. The absence of treasury single accounts means that the usual cross-checks to facilitate following the flow of funds is missing. This opens the door to rent-seeking and possible game-playing between levels of government.

In a rare admission, the Internal Evaluation Group of the World Bank notes that despite having spent $\$ 3.5$ billion in 75 countries, "having a fully functional IFMIS in place alone is not a sufficient condition for it to serve as a good budget management tool" (World Bank, 2016:23). Unfortunately, many of the systems do not track the full GFSM-classified budget with its economic, functional, program, and project classifications in the chart of accounts, which would enable the provision of accurate and timely information, including on liabilities from PPPs. And some countries with high scores in the individual budget management rankings might miss out key elements that affect the ability of and incentives for officials to "cheat", as is becoming clear for instance with the Panama papers cases, or with ongoing investigations in other countries.

Many IFMISs in emerging market economies, put in at great expense, require mapping tables to generate GFSM-consistent data for inclusion in the GFS Yearbook. In many multilevel countries, only data on central government budgetary transactions were included in the GFS Yearbook. As a result, even functional classification was excluded, and there was no information at all on provincial and local transactions. In the context of increasingly decentralized delivery of the SDG goals, this poses a significant challenge. Even senior IFI staff claim that "it may be simply illusory to expect countries to adopt budget classification and accounting system that are GFSM, if not IPSAS compliant" (Cangiano, Gelb and Goodwin-Groen, 2017:10).

Among the Emerging Market Economies (EMEs), China has made better progress than most countries (except for Russia) in addressing both the GFSM framework and Treasury Single Accounts (TSAs), in that there is a clear goal, and uniform standards are being developed. However, the reforms are not complete, especially with regard to the treatment of liabilities at the lower levels of government including in the more advanced regions of the country (see Ahmad and Zhang, 2018).

\section{SOME STYLIZED FACTS ON PPPS}

Major stylized information on PPPs is available from the World Bank's Private Participation in Infrastructure Database (https://ppi.worldbank.org). It contains 7,305 projects, recorded since 1990 with a total investment of US\$2.6 trillion. PPPs represent on average $7.5 \%$ of infrastructure investment in major EMEs, with much higher shares in some (e.g. Brazil, over 25\%), and lower in others (only about $1 \%$ in China). ${ }^{1}$ The most important sectors for PPPs were electricity, ICT, and

${ }^{1}$ While the share of PPPs in total infrastructure investment in China is very small, it needs to be kept in mind that China invests $8.6 \%$ of GDP in public infrastructure, more than North America and Western Europe combined. 
roads. There has been a sharp decline in number of projects and total investment since 2012 (figure 1). Some of this is likely related to the growing realization of the incentive problems with PPPs, particularly in multilevel countries such as India.

\section{Figure 1}

PPP projects in EMEs, 1990-2016

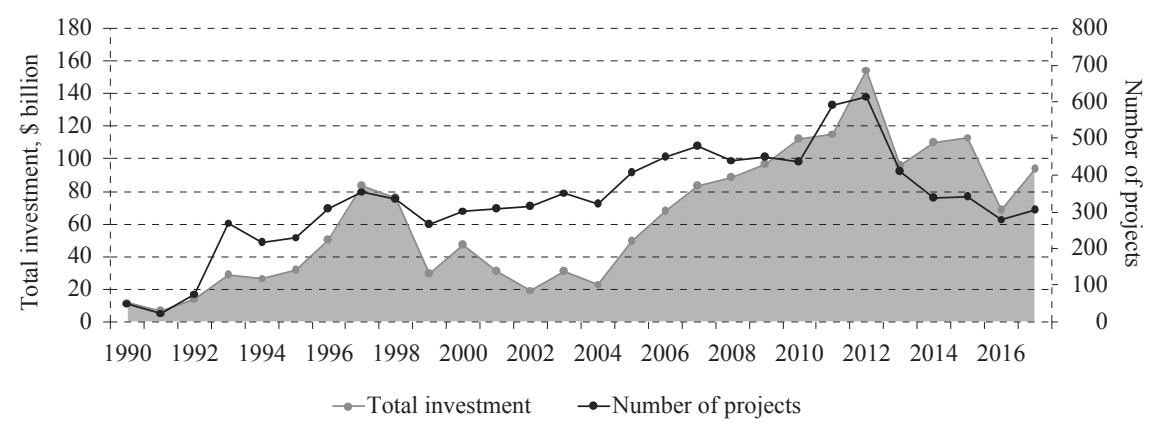

Source: World Bank, Private Participation in Infrastructure Database.

In terms of sectoral distribution (figure 2), the electricity sector has the highest number of PPP projects (with the exception of South Africa) and/or the highest allocation of resources. The ICT sector has a relatively smaller number of PPP projects (with the exception of South Africa) but it accounted for the highest, or near-highest, investment amounts. One reason could be that ICT projects are relatively large and easy to monitor at both national and sub-national levels. The importance of the ICT sector for PPPs can be also seen from figure 3, which presents a global perspective. ${ }^{2}$

\section{Figure 2}

Sectoral distribution of PPP projects in EMEs

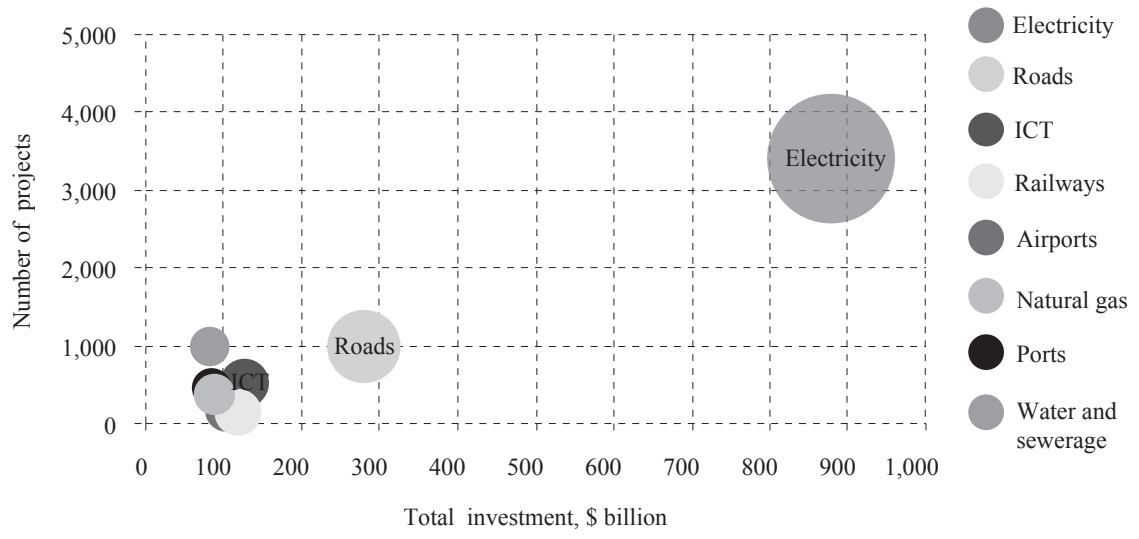

Source: World Bank, Private Participation in Infrastructure Database.

\footnotetext{
${ }^{2}$ The latest World Bank figures suggest a sharp increase in PPPs in roads and ICT in Latin America as well as East Asia and the Pacific after 2015 [see https://ppi.worldbank.org/snapshots/rankings].
} 
The World Bank dataset also contains information on cancelled and distressed PPP projects. However, these projects are included without full information from a properly designed monitoring system, so it is hard to disentangle causes of failure. It is important to distinguish whether this is due to management failure, game-playing on the part of the private partner, or failure of the government (at different levels) to provide the requisite budgetary support to cover requisite risks. As pointed out in Ahmad (2018), there are incentives for lower levels of government to pass on liabilities to a higher level, while keeping prices low to benefit local inhabitants.

\section{Figure 3}

\section{Global patterns of PPPs}
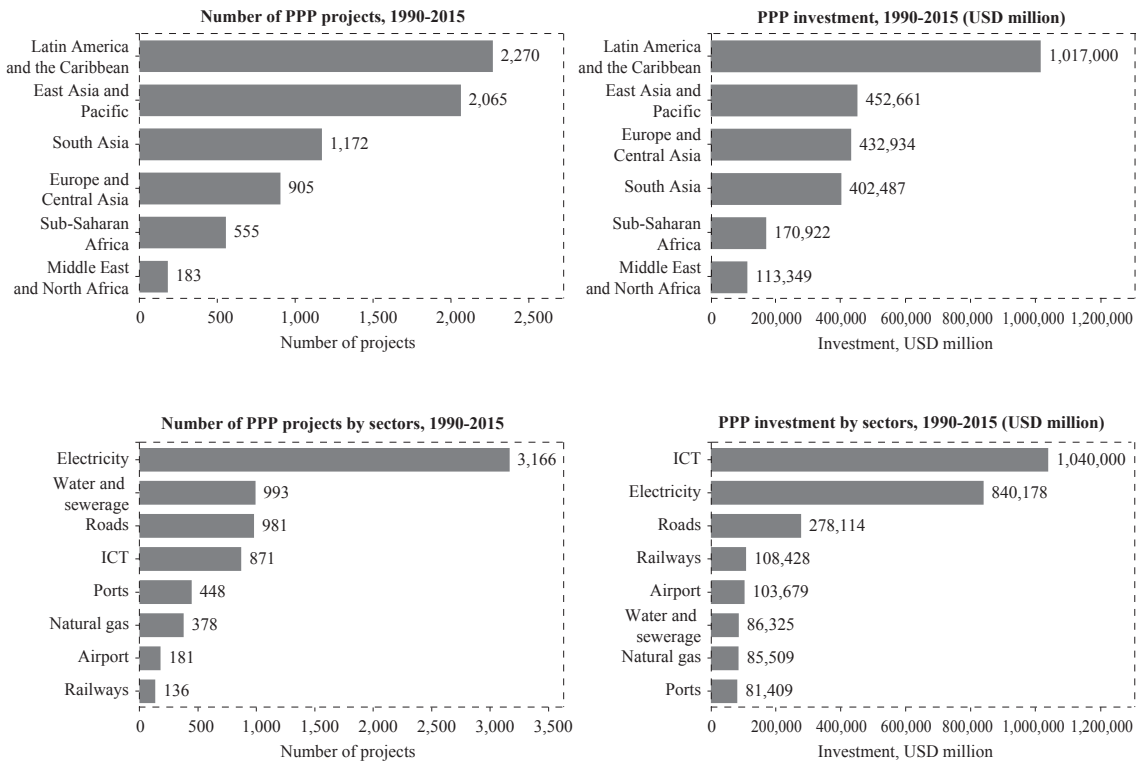

Source: World Bank, Private Participation in Infrastructure Database.

Addressing the increasing resistance of the private sector in many countries to participation in the "riskier" parts of the project life-cycle, especially the preparation and construction stages, Bhattacharya et al. (2016) recommend unbundling projects in such a way that the state undertakes the initial riskier stages, and the private sector is brought in at the operational stage, for example through securitization, when the revenue streams are clearly demarcated (see figure 4). This unbundling may well be particularly justified with respect to the uncertainty associated with climate change, as we discuss in the next section. However, the unbundling misses the efficiency gains and risk-sharing with the private sector at critical stages of the project life cycle, which are at the heart of the PPP-model. 


\begin{tabular}{|c|c|c|c|}
\hline & Preparation & Construction & Operation \\
\hline Description & $\begin{array}{l}\text { Developer/government organizes } \\
\text { feasibility studies; models cash } \\
\text { flows, finances; organizes } \\
\text { contracts with utilities, operators } \\
\text { and construction firms }\end{array}$ & $\begin{array}{l}\text { Contracted } \\
\text { construction company } \\
\text { builds the project to } \\
\text { specifications }\end{array}$ & $\begin{array}{l}\text { Separate operating } \\
\text { company takes over } \\
\text { operation and maintenance } \\
\text { of the project }\end{array}$ \\
\hline Main risks & $\begin{array}{l}\text { Macroeconomic and political } \\
\text { risks; technical risks to project } \\
\text { viability; environmental and } \\
\text { planning risks }\end{array}$ & $\begin{array}{l}\text { Macroeconomic } \\
\text { and political risks; } \\
\text { construction risks } \\
\text { (cost overrun, delay) }\end{array}$ & $\begin{array}{l}\text { Macroeconomic and } \\
\text { political risks; demand/ } \\
\text { traffic risks; operating } \\
\text { risks; policy risks } \\
\text { (e.g. tariff changes) }\end{array}$ \\
\hline \multirow[b]{2}{*}{$\begin{array}{l}\text { Cash flows } \\
\text { (stylized) }\end{array}$} & ¿ Large risks and uncertaint & over revenue streams & \\
\hline & $\uparrow$ & & \\
\hline $\begin{array}{l}\text { Financing } \\
\text { moments }\end{array}$ & $\begin{array}{l}\text { During project preparation and } \\
\text { feasibility studies, the developer } \\
\text { seeks "patient capital" or, often, } \\
\text { public funds }\end{array}$ & $\begin{array}{l}\text { Once project is } \\
\text { "bankable", the } \\
\text { developer will seek } \\
\text { equity investors and } \\
\text { debt providers to } \\
\text { finance the project }\end{array}$ & $\begin{array}{l}\text { Once construction is } \\
\text { complete and operation } \\
\text { starts, project can be } \\
\text { refinanced to reflect the } \\
\text { changing risk profile }\end{array}$ \\
\hline
\end{tabular}

Source: Bhatttacharya et al. (2016).

\section{DRAWING PRACTICAL CONCLUSIONS ON PPPS AND CONTRACTUAL ARRANGEMENTS FROM CONTRACT THEORY}

In this section we review some of the new literature on alternative contractual options including PPPs. This enables us to address some very relevant policy concerns, such as the need to ensure greater efficiency and risk sharing with the private sector, relieving administrative constraints, and bringing in private sources of financing. PPPs should not be seen as a device for "kicking the fiscal can down the road." Consequently, for an effective utilization of the opportunities inherent in the PPP model, the multilevel fiscal regime and associated business climate agenda need to be properly delineated, including the incentives associated with own-source taxes and information flows concerning public liabilities.

\subsection{TYPES OF CONTRACTS}

Williamson (1985) showed that under some conditions a public firm may exactly replicate the performance of a private firm and be equally efficient (i.e., minimize cost). In that case there is no efficiency loss in letting a public firm produce some public good or run some facility.

On the other hand, Sappington and Stiglitz (1987) show that privatization can replicate public provision in terms of productive efficiency, equity, and rent extraction. When this is the case, privatization can be an optimal solution to the delegation problem. But there are two conditions. First, it should be possible to 
draw up a complete contract to account for any contingencies, and the government should be able fully to commit to that contract. Second, the government (or policy maker) should be benevolent, i.e., pursue the social interest. The equivalence fails and ownership becomes relevant when one of these requirements is not satisfied. In particular, when contracts are incomplete, ownership matters even with a benevolent government.

Laffont and Tirole $(1991,1993)$ and Schmidt (1996a, 1996b) show why contractual incompleteness matters in the relationship between the public and private sectors. First, there is an informational asymmetry about the relevant costs and benefits of the project between the (benevolent) policymaker and the delegated manager. Second, the investments made by the manager are non-verifiable and non-contractible. This gives rise to trade-offs between productive and allocative efficiency. Under public ownership, once the cost of investment is sunk, the government cannot refrain from expropriating (part of) the associated benefits from the manager. Then, a hold-up problem arises, which leads to underinvestment. Under private ownership, the government can credibly commit not to expropriate the investment, but informational asymmetries are more costly to address. Then allocative inefficiencies may arise. Hence the first practical conclusion.

\section{Practical conclusion 1}

In incomplete contracting frameworks where investments made by the project developer are non-contractible, projects should be privatized when hold-up problems are severe (and thus can lead to high productive inefficiencies) and remain public when information problems are costly (and thus can lead to high allocation inefficiencies).

To summarize, if imperfections only ensue from information problems (moral hazard and adverse selection), but complete contracts can be signed, ownership does not matter. Intuitively, an owner has no special power or rights when all project aspects are specified in a contract. Under contractual incompleteness, the owner, whether public or private, has the "residual control rights"; he therefore makes all the decisions required to develop the project on which the contract is silent (Hart, 2003).

Studies of governments with private agendas that overlap and interfere with social objectives help us understand why such non-benevolent behavior matters for project ownership. Private (regulated) ownership limits policymakers in the pursuit of their private agendas (rent-seeking), subject to institutional arrangements and degree of competition. At the same time, if governments are less informed about the relevant costs and benefits of the projects than private project managers, public ownership helps avoid allocative inefficiencies. Obviously, the desirability of private ownership depends on the balance between these two considerations (Shapiro and Willig, 1990). 


\section{Practical conclusion 2}

When governments are non-benevolent, projects should be privatized if the private agendas of officials induce pronounced rent-seeking. Projects should remain public when it would be too costly for the government to obtain information about the costs and benefits of the private project partner.

Under some circumstances, the boundaries between public and private firms are difficult to identify. While ownership structures matter when contracts are incomplete, many investment projects are too complex to be analyzed within an incomplete contracts framework. Consistent with this, in public debates, privatization often refers to entrusting private parties with the governing authority and managerial responsibilities that are not necessarily paired with a transfer of asset ownership. Accordingly, contracts on the privatization of infrastructure projects specify not only the transfer of ownership rights, but also attribute responsibilities about design, construction, maintenance and modernization. In this perspective, the choice between public and private ownership is not disjoint from the assignment of investment tasks.

Practical limits to the idea of separating the ownership of infrastructure projects are particularly visible when access to the assets is essential to implement innovations. Two options can be envisaged in such a case, which Hoppe and Schmitz (2010) refer to as two kinds of public-private partnership. Under the first, both parties are assigned veto power on implementation. This is tantamount to joint ownership. Under the second, neither party has veto power. The government has the right to implement quality innovations (which are beneficial to society) and the manager has the right to implement cost innovations (which make the project cheaper).

Within this framework, two conclusions can be drawn. First, given the ownership structure, it is possible to understand what the optimal allocation of investment tasks looks like by considering the pattern of investment induced by that particular structure. Second, it is possible to identify the preferable ownership structure, which will depend on the importance of the cost innovation and side effect on quality; the importance of the quality innovation and its side effect on the cost; and the bargaining power of the public and the private parties.

\section{Practical conclusion 3}

In incomplete contracting frameworks, where the government and the private manager share the same information, and investments in quality and cost innovations are contractible control actions, the optimal allocation of investment tasks depends on whether ownership is private or public, or a partnership is formed. Under private ownership, the manager should be entrusted with the investment in cost innovation; which party should be in charge of the investment in quality innovation depends on the parties' bargaining powers. Under public ownership, the government should maintain the responsibility for the investment in quality 
innovation; which party should be in charge of the investment in cost innovation depends on the parties' bargaining powers. In a partnership, there should be no veto power. The government should maintain the responsibility for the investment in quality innovation; the manager should be entrusted with the investment in cost innovation.

This conclusion can be explained as follows. Private ownership strengthens the incentives to engage in cost-reduction activities, because the benefits of those activities can be fully appropriated while attaining an efficient level of investment. ${ }^{3}$ By contrast, private ownership reduces the incentives to engage in quality improvements and gives rise to underinvestment. In turn, public ownership strengthens the incentives to engage in quality-enhancing activities, in which the efficient level of investment is attained, and reduces the incentives to engage in cost innovations, which gives rise to underinvestment. ${ }^{4}$ A partnership without veto power warrants implementation of both cost-reduction and quality-enhancing innovations, replicating the incentives for cost innovations under private ownership and the incentives for quality innovation under public ownership. However, it is unlikely that the two investments occur with efficient size. In fact, one should expect overinvestment to arise in one dimension and underinvestment in the other. ${ }^{5}$

\section{Practical conclusion 4}

In an incomplete contracting framework, where the government and the private manager share the same information and investments in quality and cost innovations are contractible control actions, a partnership with no veto power is preferred to a single ownership when (1) the parties' bargaining powers are not very different, and (2) the side-effects of the quality and cost innovations are relatively less important. A single ownership is preferred when (1) the parties' bargaining powers are unbalanced, and (2) the side-effect of one innovation is important relative to that of the other. Private ownership is preferred when the sideeffect induced by the quality innovation on cost is relatively strong. Public ownership is preferred when the side-effect induced by the cost innovation on quality is relatively strong.

\footnotetext{
${ }^{3}$ This outcome arises when, as considered by Hoppe and Schmitz (2010), the parties agree on setting the quantity (not excessively) below the efficient level in the contracting stage. That quantity can then be upgraded to the efficient level in a later renegotiation. This possibility looks highly plausible as, in practice, it is often the case that the scope of the project is revised and scaled up during its development. If the quantity is set to the efficient level already in the initial contract, then overinvestment in cost innovations arises under private ownership, because, as found in Hart, Shleifer and Vishny (1997), the side effect of the cost-reducing activities on quality is not internalized. On the other hand, too small a quantity leads to underinvestment, because the manager does not fully appropriate the benefits generated by the investment in the renegotiation stage. An important lesson arises from these results. Extending the scope of public projects during their development and, hence, letting the projects become less cheap than initially planned, may be a deliberate choice to address the overinvestment problems that would arise if a bigger size were fixed up-front.

${ }^{4}$ The same observation on the choice of the quantity level applies in this case.

${ }^{5}$ Again, this is related to the quantity choice made by the parties in the initial contract. In this case, the quantity is a single incentive tool to be used to pursue two goals, namely induce an efficient investment in cost reduction and quality enhancement. In general, the quantity that secures the former goal differs from the quantity that secures the latter, and none of the two goals is achieved as a result of the bargaining process between the parties.
} 
This conclusion is intuitive. When one party has strong bargaining power, the critical limit of the single ownership, namely the issue of underinvestment, is less important. What matters is to attain the efficient level of investment in the innovation that is deemed to be important. A partnership is thus less appropriate. When the bargaining power is equal between the parties, the issue of underinvestment in one task - either cost reduction or quality enhancement - is more important. This makes a partnership a more appropriate solution. Of course, the reach and implications of this conclusion cannot be fully understood without identifying what determines the bargaining power of the public and the private party. As Hoppe and Schmitz (2010) suggest, this might be related to the degree of competition.

\subsection{BUNDLING OR UNBUNDLING?}

In drawing up practical conclusions 3 and 4, we have followed Hoppe and Schmitz (2010) and referred to "partnerships" as arrangements under which either the public and the private party both have veto power on the implementation of innovations, or neither has veto power but each is in charge of a single innovation. PPPs are essentially meant to be contractual arrangements for the development of infrastructure projects with the following key characteristics: first, the construction of the infrastructure and its subsequent management for the provision of a service are bundled and assigned either to a single private contractor or to a consortium of private firms. Second, sometimes the bundle includes also other phases of the project, such as design and finance.

Bundling places PPPs in sharp contrast with traditional procurement, under which the private sector is also involved, but the responsibilities for the different phases of the project are assigned to different private contractors. Therefore, PPPs are intrinsically longer-term than procurement relationships.

There is also a second feature that differentiates PPPs from traditional procurement. Under a PPP, the government specifies the outputs, namely the service to be delivered and the essential standards to be complied with, whereas the control rights over the ways of accomplishing tasks are transferred to the private contractor. Throughout the duration of the PPP, the private contractor is responsible for the infrastructure, may implement innovative systems for service supply, and may even use the infrastructure for other income-generating activities (provided that the standards specified in the PPP contract are not diminished). At the end of the contract, either the infrastructure returns to the public sector or it remains with the private sector, depending on the specific contractual arrangement.

By contrast, under traditional procurement, the government specifies the inputs and preserves the ownership of the infrastructure during the contractual period and thereafter. Accordingly, one may consider a PPP as being tantamount to private ownership with bundling of subsequent activities, and traditional procurement as being tantamount to public ownership with unbundling and delegation of subsequent activities to different private contractors (Bennett and Iossa, 2006). 
There are various criteria to be used and aspects to be considered to establish when the PPP-type institutional arrangement in infrastructure projects is preferable to the unbundled. These criteria depend on the terms of residual value and optimal ownership of the infrastructure after the contracts end. This is a major concern for public infrastructure projects with long-term private investments.

The first aspect that matters and, hence, can be used as a criterion to establish a preference between PPPs and traditional procurement, pertains to the nature of the links (if any) between the subsequent phases of the project. To examine this aspect, Bennett and Iossa (2006) use an incomplete contracting model with two subsequent project stages, namely construction of the infrastructure and management and provision of the public service. They represent situations in which investments are non-contractible - as is the case with the delivery of innovations - but ex-post verifiable, because once innovations have been discovered their implementation can be verified. Accordingly, the owner of the infrastructure during the execution of the project is allocated the right to decide on the implementation of the innovations. The implication is that under private ownership (PPP) the contractor decides freely whether to implement an innovation or disregard it. Under public ownership (procurement) any innovation requires a new negotiation with the contractor, the implementation of innovation can then be either permitted or not.

\section{Practical conclusion 5}

Bundling is preferable when there are positive externalities between the subsequent phases of the project. The case for bundling is weakened when there are negative externalities between the subsequent phases of the project. Unbundling is preferable with weak externalities, especially if the provision of the service is long-term.

For instance, a positive externality (or synergy) arises when building a highquality infrastructure reduces the cost of management in the operation stage. When the high quality of the infrastructure, while enhancing the social benefit of the project, increases the cost of management, the externality is negative, instead.

Intuitively, PPPs perform better in the presence of positive externalities because the latter are optimally internalized when project phases are bundled. Bundling strengthens both incentives to innovate and reduce the costs over the lifecycle of the project. Traditional procurement performs better with weak negative externalities, as internalization is then either irrelevant or less desirable. On the other hand, internalization of negative externalities exacerbates the issue of underinvestment. The same issue arises in the hold-up problem under incomplete contracting noted above. If externalities are weak and the operation phase is long, then project bundling restricts competition without providing positive incentives to reduce costs or improve quality. 


\section{Practical conclusion 6}

In the presence of positive externalities, control rights on the innovations should be assigned to the private contractor, if the effects in terms of cost and residual value of the infrastructure are strong relative to those on the social benefit. In the converse case, control rights should be assigned to the government. In the presence of negative externalities, control rights should be assigned to the private builder of the infrastructure, if the effects in terms of residual value of the infrastructure are relatively strong. If the effects in terms of social benefit are relatively strong, control rights should be assigned to the government.

The intuition behind this conclusion is not very different from that underlying practical conclusion 2. We will rather turn to considering the ownership in the post-contractual period.

\section{Practical conclusion 7}

With positive externalities between project phases, bundling is desirable regardless of whether the infrastructure returns to the public sector or remains with the private contractor after the end of the contract.

If the infrastructure becomes public after the end of the contract, a concern arises with the incentives to invest in innovations by the private partner. The impact on incentives will depend on how and under what conditions the return to public ownership takes place. Innovation incentives are reduced if an automatic transfer clause is introduced in the PPP contract. Hence, clauses of this kind are to be avoided. Innovation incentives are reinforced if the choice is made through a voluntary negotiation and the partners reach an agreement on a compensation payment to the private contractor. This is obviously a better strategy to follow in terms of innovation incentives. The negotiation strategy also strengthens the case for PPPs relative to traditional procurement, especially for projects/services that do not attract strong political or social opposition to the long-term private ownership of infrastructure.

A more nuanced view becomes possible when one goes beyond the externalities case and considers interdependence of the different project tasks. As Chen and Chiu (2010) point out, interdependence of tasks may lead to substitutability: making more of one investment decreases the benefits of making more of another investment. For instance, constructing a high-quality hospital reduces the operational cost once the hospital is finished, but makes it less likely that further improvements in the quality of the hospital facility will be made, or that it will be used for alternative purposes. Interdependence of tasks may also lead to complementarity: making more of one investment increases the benefits of making more of another investment. For instance, installing higher-quality but more expensive glass in the windows of a school reduces the operational cost; in addition, it may be worthwhile to install a surveillance system to protect windows from vandalism. 
This classification of tasks helps us to understand a circumstance in which the exact terms under which the service will be provided in the operation stage are not defined until after the infrastructure is built, even though operation by the private contractor is accounted for in the contract. It is also useful for thinking about greenfield projects, in which preserving flexibility in the contracting stage helps arrangements to be modified at a later stage, when the project becomes more mature and the initial uncertainty dissipates. ${ }^{6}$

\section{Practical conclusion 8}

In a framework with interdependence of investment tasks and interim contractibility of the task to be accomplished in the operation stage, substitutability favors bundling. Under private ownership, it also favors the PPP consortium for the entire life-cycle of the project, arranged through a separate direct contract with the builder during the construction stage. ${ }^{7}$ Complementarity favors unbundling and, under private ownership, a separate builder's contract for the construction stage. Under public ownership, for instance by state-owned enterprises, integration and separation of tasks are equivalent.

When the tasks are separated (unbundled), complementarity is helpful in lessening the incentives to underinvest in the construction stage, which result from the usual hold-up problem. As mentioned above, complementarity involves more investment in the construction stage triggering more investment in the operation stage. Thus, with complementary tasks, the private builder will be more motivated to invest, anticipating that this will induce the manager to invest more and that more surplus will be generated. As the operating task can be negotiated at interim, the builder can negotiate with the manager how they will share the benefits of the operating investment. The sharing will depend on the size of the investment initially made by the builder, whereas the cost of the operating investment will remain with the manager only. This explains why complementarity favors the builder's ownership/full PPP contract. On the contrary, when the tasks are bundled, complementarity weakens the incentives to invest in the construction stage because the private contractor internalizes the impact on the later investment not only in terms of benefits but also in terms of costs.

Under public ownership, integration and separation are equivalent because, on the one hand, the operating investment can be contracted upon at interim and, on the other, the government can veto the implementation of the building innovation after the investment has been made.

\footnotetext{
${ }^{6}$ Projects are said to be greenfield when they are totally new. They require designing, financing and building in the early stages; and operating and maintaining in the late stages (these tasks can, of course, be accomplished under different possible institutional arrangements). By contrast, brownfield projects rest on previously existing assets so that such tasks as design and construction are of a more limited importance. As developing countries are very poorly endowed with existing infrastructure they are much in need of greenfield projects. The conclusions presented in the text are therefore potentially very relevant for developing countries. ${ }^{7}$ Recall that in PPPs the private partner is often a consortium of private firms (rather than a single firm), and that it is in charge of all the phases of the project (rather than solely the construction phase).
} 
It is useful to relate this to practical conclusion 5. According to the latter, negative externalities between tasks weaken the case for bundling relative to separation. It has sometimes been argued that negative externalities are almost negligible in practice. This would mean that bundling should be observed in nearly all projects. However, that conclusion should be refined in light of practical conclusion 8 . Unbundling is a desirable option even in the presence of (not-too-pronounced) synergies, when the project tasks display sufficiently strong complementarity. Chen and Chiu (2010) discuss this point in light of projects of a different nature (e.g. schools and information technology projects as cases of complementarity, prisons and transport as cases of substitutability).

\section{Practical conclusion 9}

In a framework with interdependence of investment tasks and interim contractibility of the task to be accomplished in the operation stage, private ownership is preferable when the residual value of the infrastructure is high and the social value of the project is low. Public ownership is preferable in the converse case.

So far, we have identified several features of the projects and the contractual environments under which bundling (hence, PPP) is preferable to an institutional arrangement that separates and assigns tasks to different contractors. As the relationship between public and private agents is of a longer-term nature under bundling, innovation incentives that arise to project developer have to be contrasted with a potential drawback of bundling, i.e. the scope for informational asymmetries to develop over time. This implies that a PPP may or may not perform better than traditional procurement over the long term, depending on the incentives of the private contractor to gather information for strategic reasons.

Hoppe and Schmitz (2013) develop a model in which the initial contract details only the basic features of the project, whereas additional specifications can be agreed upon later, when the operation phase is to begin and it is then apparent how to improve the project to match the social needs. Again, the interim contractibility of subsequent (ex-post verifiable) investments is meant to capture the necessity of preserving flexibility for future adaptation, as also accounted for in Bennett and Iossa (2006), and Chen and Chiu (2010). Of course, the second-stage improvements are costly. Hoppe and Schmitz (2013) focus on situations in which the cost is not known in the construction stage, but the private builder can devote some resources to gather information about it. Information gathering is socially wasteful in that the cost will become known without exerting any effort in the operation stage. The contractor can nonetheless decide to acquire information in order to appropriate more surplus in a later stage of relationship with the government (a rent-seeking strategy). Whereas the institutional arrangement would be irrelevant in the absence of informational asymmetries between the public agency and the private contractor, it does matter when the latter enjoys an informational advantage. 


\section{Practical conclusion 10}

In a framework with early design innovation, interim contractibility of the operating investments, and strategic gathering of information on the cost of those investments, traditional procurement is preferable when the government can rely on some precise signal of the effort exerted in innovation, information gathering is cheap, and great importance is attached to the surplus accruing to the private contractor. PPPs are preferable otherwise.

Under traditional procurement, the government must provide a reward to motivate the contractor to come up with an innovative design in the early stage of the project. The reward is typically based on some signal of the effort exerted to attain the agreed-upon outcome. For the contractor protected by limited liability, this involves granting a rent.

Under a PPP, there is less need of a direct reward. The contractor will be motivated to innovate early in the project, anticipating that she will enjoy a rent if she makes that effort and then gathers information (not available to the government) on the future cost. The perspective of attaining that rent permits a reduction in the rent to be conceded due to limited liability. The PPP thus provides a useful tool to motivate the private contractor to develop a design that is flexible enough to respond to the future social preferences in a cost-effective manner. However, the rent in the form of strategic information gathering is not socially desirable, and the PPP project in this case will actually be less cheap than it might have been if resources had not been disbursed for strategic purposes. ${ }^{8}$

In several cases, especially involving climate change, the investments made in the early stages of the project do not simply affect the environment in which later investments will be made. When irreversible, the early investments may represent a constraint to the later investments. For instance, if high-quality investments are made in the water, transport, or electricity systems early in the projects, the contractor is committed thereafter to make high operation and maintenance expenditures to maintain the viability of the project. This is potentially problematic when future conditions are uncertain in the early stage of the project. Indeed, irreversibility leads to rigidities, i.e. it makes it difficult to adapt the project to the environmental conditions that will be discovered only at a later stage. It is thus not surprising that irreversibility will affect the incentives and the decisions of the

\footnotetext{
${ }^{8}$ Hoppe and Schmitz (2013) point out that these results are robust to the possibility that the government does not observe information gathering. However, in that case ex-post inefficiencies may arise under PPP. Che, Iossa and Rey (2017) also conclude that rents matter. They consider an environment where the procurer pursues two goals: incentivizing research effort to create a new idea, and implementing the new idea in a least costly manner. Provided that the research effort is unverifiable and that the cost of implementing the innovation is privately known, the procurer faces moral hazard ex ante and adverse selection ex post. The implementation of the idea should be assigned to the innovator (that is, the follow-up should be bundled with the initial contractor) when the value of the innovation is sufficiently high. In that case, the rents accruing to the innovator represent a powerful incentive tool. By contrast, the implementation of the idea should be assigned to a contractor other than the innovator (that is, the follow-up should be separated with a new contractor) when the value of the innovation is low. In that case, the rents accruing to the innovator are greater than incentives to innovate, raising the opportunity cost of favouring the innovator.
} 
contractor in the subsequent stages. These considerations have implications for the desirability of different institutional arrangements and bundling at subsequent stages relative to a sequence of shorter-term contracts with different contractors.

Martimort and Straub (2016) examine bundling in a two-period model with uncertainty, in which a non-verifiable and costly effort (investment) is exerted in each period. Higher effort makes it more likely that the social return to the project will be above its basic social value. Non-verifiability and irreversibility influence the incentives to invest early in the project. A dynamic moral hazard problem arises and rents are generated under limited liability. ${ }^{9}$

\section{Practical conclusion 11}

In an incomplete contracting framework with uncertainty, unverifiable irreversible investments, and limited liability, bundling tasks in a long-term contract is desirable when commitment concerns prevail. Unbundling and providing for a sequence of shorter-term contracts with different contractors is desirable when flexibility concerns prevail.

The government agency can structure the intertemporal profile of rewards to the contractor in charge of the project in such a way that the contractor will find it convenient to raise the early investment, thus also creating a commitment to high investment at a later stage. However, the contractor's reaction will also depend on how he or she values the preservation of flexibility. A responsive contractor will make large investments in both early and later stages due to the commitment effect induced by the initial investment. A less responsive contractor will invest little in the early stage and, hence, will be free to choose any convenient level of investment later in the project, when uncertainty will be resolved. To understand why the issue of underinvestment is mitigated if the second stage of the project is separated from the first and delegated to a different contractor, it is useful to consider that irreversibility works as a negative externality between investments. We recall from practical conclusion 5 that negative externalities weaken the case for bundling tasks. Separation mitigates the issue of underinvestment because, following the early irreversible investment, the second contractor will enjoy less flexibility and be committed to investing.

As usual, the most appropriate organizational form is not a one-for-all solution. It depends on several elements, as Martimort and Straub (2016) show, including:

\footnotetext{
${ }^{9}$ The authors point out that what they refer to are investments intended to raise the efficiency (or quality) of the project, in addition to any well-defined investment related to, say, the contractually specified size of the physical assets. This latter kind of investment is verifiable and, hence, could be disciplined through the contract. One might expect the moral hazard problem associated with non-contractible investments to be especially severe when the physical assets to which the contractible investments pertain are network infrastructures (such as rail and road systems) rather than stand-alone facilities (such as schools and hospitals) and pointto-point infrastructures (such as ports and airports). This is because the former are more complex systems, require higher sunk costs, and are exposed to less competition. Considerations of this kind lead Albalate, Bel and Geddes (2015) to suggest that jurisdictions inexperienced in contracting out infrastructure projects begin with stand-alone facilities and point-to-point infrastructures, and move to network infrastructures only after acquiring sufficient expertise.
} 
(1) the presence of rents associated with the moral hazard problem and the availability of instruments to contain them; (2) the sector concerned or kind of project and the environmental specificities; and (3) the likelihood of future technological improvements in a given sector/kind of project.

\section{Practical conclusion 12}

In an incomplete contracting framework with uncertainty, unverifiable irreversible investments, and limited liability, the case for bundling tasks in a long-term contract is stronger when: (1) there are instruments to contain limited liability rents; (2) the sector/kind of project concerned is less exposed to the adverse consequences of unpredictable events; and (3) technological improvements are expected to enhance flexibility.

In practice, conceding rents is necessary to address moral hazard, because contractors are generally protected by limited liability (or are risk averse). Moral hazard is more easily addressed if there are ways to reduce the rents (i.e. the stake for opportunistic behavior). This could be achieved, among other ways, by tightening competition in the tendering stage, boosting diversification through the acquisition of financial bonds (so as to reduce the need for insurance within the contractual relationship), and/or introducing risk- and revenue-sharing mechanisms. ${ }^{10}$

Local public goods provide a good example of sectors and projects with prominent commitment concerns that are less exposed to the potential consequences of unpredictable events, particularly those associated with climate change. Water and sanitation networks and power production projects belong to the category of sectors and projects that are heavily exposed to flexibility concerns. However, Borenstein (2012) emphasizes that even generation plants with similar technologies will not have the same exposure, as they are highly heterogeneous in location, architecture, and other elements.

Sometimes technological improvements may grant technological flexibility, which may work as a substitute for contractual flexibility. When this is the case, it becomes less important to preserve flexibility by reducing investments early in the project. If so, the case for unbundling is weakened. However, technological improvements cannot be taken for granted (Biglaiser and Riordan, 2000). For instance, they are less likely in water and sanitation systems, and highly plausible in energy projects, favoring bundling in the former case, and making the choice less clear-cut in the latter.

\subsection{MULTILEVEL CONSIDERATIONS}

Multilevel governance conditions are important. In general, central governments, which are typically in charge of water and energy policy, should be well prepared to design and follow up short-term contracts, while local governments, which are

\footnotetext{
${ }^{10}$ Mechanisms of this kind are already in use in many utilities and projects such as greenfield concessions for toll highways, as reported in Iossa (2015). Of course, this calls for fine-tuning complementary institutional mechanisms and raises potential concerns related to social equality considerations.
} 
typically in charge of local public goods, should be well prepared to design and follow up PPPs. However, this conclusion may be problematic on several grounds.

PPP contracts may be too complex for many local governments to implement, so they should ideally receive technical support from a central PPP-management body, perhaps supported by international agencies. The liabilities associated with PPP contracts should be recorded in the local government balance sheets. This requires both the GFSM and IPSAS standards to be implemented. Not doing so proved problematic in EU countries (see Ahmad, Bordignon and Brosio, 2016). For instance, France has just required local administrations to begin doing so. In particular, it is essential for local governments to have access to local own-source revenues in order to limit the creation of liabilities within a medium-term budget framework and lessen the incentives to engage in strategic game-play with the central government. This issue is critical in the context of the SDGs (see Ahmad, Brosio and Gerbrandy, 2017).

When the bundling solution is preferable, an additional conclusion can be drawn concerning the preferable form of PPP to be used. As Martimort and Straub (2016) highlight, this also raises the question whether the infrastructure should return to the public sector or be privatized after the contract ends.

\section{CONCLUDING REMARKS}

This paper highlights the interactions of sustainable investment decisions with tax policy options and institutional arrangements and information flows that influence incentives facing firms, households and governments at different levels.

Equally important are the interlinkages between information flows and governance institutions, including public finance management prerequisites such as recording public liabilities (including subnational governments and state-owned enterprises) in general government balance sheets. Despite the pessimism of some senior staff of international financial institutions (e.g. Cangiano, Gelb and Goodwin-Groen, 2017), both the GFSM and IPSAS standards are needed, not to report to the IMF but as tools of active macro-management and accountability at different levels of government. Without full information on the nature, generation and time-profile of liabilities, PPPs can easily become opportunities to "kick the fiscal can down the road", and create opportunities for "game-play" between different levels of government and between the private and public partners. As highlighted in Ahmad and Zhang (2018), full information is needed also with respect to stateowned enterprises, particularly at the local level.

The choice between alternative contractual arrangements at different stages of the project life-cycle turns on the need to bring in private expertise, risk-sharing, and private finance. The contractual options range from traditional public procurement to PPPs of various types. Asymmetric information makes it possible for the private partner to extract extra rents, and for local governments to hide liabilities. But the 
private sector may just not be interested in earlier and riskier stages of the project life cycle due, perhaps, to lack of credibility of contracts or rent-seeking. This is where multilateral agencies able to guarantee that contracts will be respected come into play.

Bhattacharya et al. (2016) argue that different stages should be "unbundled" or treated separately, so that the private sector is brought in when there is a steady stream of income. However, entering into PPPs at the operational stage may be tantamount to privatizing the benefits but socializing the risks. Bhattacharya et al. (2016) refer to "securitization" rather than PPPs at the operational stage. This may well be the appropriate option, particularly with respect to uncertainty associated with climate change (Martimort and Straub, 2016). In this vein, Arezki and Sy (2016), suggest with reference to African countries that development banks should provide financing in the early phases of the infrastructure projects when risks are particularly high.

But there are distinct advantages with "bundling" and full risk sharing with the private sector in all stages of the project life cycle, especially where there is interdependence between activities at the different stages. This may be critical to innovation, efficiency, and overall cost.

The contract choices can be quite complex. A national office dealing with the operational, legal, and regulatory arrangements, as well as dispute-resolution may be needed. Technical support from countries (including the EU as well as major Asian countries) with experience in designing and managing infrastructure programs may be quite helpful in this regard. Multilateral development banks have considerable expertise in this area, with repositories of case studies. They could usefully reorient their traditional activities concerning and support to developing and emerging market economies so as to support sustainable development. The options include better articulation of the overall growth strategy and parameters for project selection; interactions with the tax regime at the national and local levels, particularly the role of local property taxes to anchor local investments and service delivery and generate accountability; identification of local growth hubs; improved formulation and implementation of support for IFMISs to focus on the tracking of liabilities at all levels of government, particularly the GFSM framework and IPSAS standards; support for contracting arrangements at national or local levels so as to prevent egregious rents; exchange of information on successful as well as problematic implementation cases; and ensuring that contracts are respected.

Together, the options presented here represent a formidable research and policy agenda for designing and implementing sustainable growth strategies and programs.

\section{Disclosure statement}

No potential conflict of interest was reported by the authors. 


\section{REFERENCES}

1. Ahmad, E., 2017. Public Investment for Sustainable Development. G24 Background Paper. Available at: <https://www.g24.org/wp-content/uploads/2017/ 09/Public_Investment_for_Sustainable_Development.pdf $>$

2. Ahmad, E., 2017a. Political Economy of Tax Reforms for SDGs: Improving the Investment Climate; Addressing Inequality; Stopping the Cheating. G24 Background Paper. Available at: <https:/www.g24.org/wp-content/uploads/ 2017/09/Political_Economy_of_Tax_Reform_for_SDGs.pdf $>$

3. Ahmad, E. [et al.], 2018. Involving the Private Sector and PPPs in Financing Public Investments. G24-GGGI Infrastructure Working Paper, No. 5. in: E. Ahmad, M. Niu and K. Xiao. Fiscal Underpinnings for Sustainable Development in China - Rebalancing in Guangdong. Springer, pp. 123-162.

4. Ahmad, E., Bordignon, M. and Brosio, G., 2016. Multilevel Finance and the Eurocrisis. London: Edward Elgar.

5. Ahmad, E., Brosio, G. and Gerbrandy, J. 2017. Property Taxation Incentives for Meeting the SDGs in Developing Countries. European Commission Study FED/2016/380-048.

6. Ahmad, E., Niu, M. and Xiao, K. (eds.), 2018. Fiscal Underpinnings for Sustainable Development in China - Rebalancing in Guangdong. https://doi. org/10.1007/978-981-10-6286-5

7. Ahmad, E. and Zhang, X., 2018. Towards Monitoring and Managing Subnational Liabilities in China: Lessons from the Balance Sheet for County K in: E. Ahmad, M. Niu and K. Xiao. Fiscal Underpinnings for Sustainable Development in China - Rebalancing in Guangdong, pp. 71-94.

8. Albalate, D., Bel, G. and Geddes, R. R., 2015. The determinants of contractual choice for private involvement in infrastructure projects. Public Money \& Management, 35(1), pp. 87-94. https://doi.org/10.1080/09540962.2015.986898

9. Arezki, R. and Sy, A., 2016. Financing Africa's infrastructure deficit: From development banking to long-term investing. Global Views, No. 2. https://doi. org/10.1093/jae/ejw017

10. Bennett, J. and Iossa, E., 2006. Building and managing facilities for public services. Journal of Public Economics, 90(10-11), pp. 2143-2160. https://doi. org/10.1016/j.jpubeco.2006.04.001

11. Bhattacharya, A. [et al.], 2016. Delivering on Sustainable Infrastructure for Better Development and Climate Change. Washington: Brookings Institution.

12. Biglaiser, G. and Riordan, M. H., 2000. Dynamics of Price Regulation. Rand Journal of Economics, 31(4), pp. 744-767. https://doi.org/10.2307/2696357

13. Borenstein, S., 2012. The Private and Public Economics of Renewable Electricity Generation. Journal of Economic Perspectives, 26(1), pp. 67-92.

14. Cangiano, M., Gelb, A. and Goodwin-Groen, R., 2017. Digitization of Government Payments as a Key Tool of Modern Public Financial Management. IMF Conference on Digital Revolution in PFM, April 23-24. 
15. Che, Y.-K., Iossa, E. and Rey, P., 2017. Prizes versus Contracts as Incentives for Innovation. CEPR Discussion Paper, No. DP11904. Available at: <https:// papers.ssrn.com/sol3/papers.cfm?abstract_id=2934216>

16. Chen, B. R. and Chiu, Y. S., 2013. Public-Private Partnerships: Task interdependence and contractibility. International Journal of Industrial Organization, 28(6), pp. 591-603. https://doi.org/10.1016/j.ijindorg.2010.02.002

17. Hart, O., 2003. Incomplete Contracts and Public Ownership: Remarks, and an application to public-private partnerships. The Economic Journal, 113(486), pp. C69-C76. https://doi.org/10.1111/1468-0297.00119

18. Hart, O., Shleifer, A. and Vishny, R. W., 1997. The Proper Scope of Government: Theory and an Application to Prisons. Quarterly Journal of Economics, 112(4), pp. 1126-1161. https://doi.org/10.1162/003355300555448

19. Hoppe, E. I. and Schmidt, P. W., 2010. Public versus Private Ownership: Quantity contracts and the allocation of investment tasks. Journal of Public Economics, 94(3-4), pp. 258-268. https://doi.org/10.1016/j.jpubeco.2009.11.009

20. Hoppe, E. I. and Schmidt, P. W., 2013. Public-Private Partnerships versus Traditional Procurement: Innovation incentives and information gathering. Rand Journal of Economics, 44(1), pp. 56-74. https://doi.org/10.1111/17562171.12010

21. Iossa, E., 2015. Contract and Procurement Design for PPPs in Highways: The road ahead. Economia e Politica Industriale, 42(3), pp. 245-276. https://doi. org/10.1007/s40812-015-0014-5

22. Laffont, J. J. and Tirole, J., 1991. Privatization and Incentives. Journal of Law, Economics and Organization, 7, pp. 84-105. https://doi.org/10.1093/jleo/7. special_issue. 84

23. Laffont, J. J. and Tirole, J., 1993. A Theory of Incentives in Procurement and Regulation. Cambridge: The MIT Press.

24. Martimort, D. and Straub, S., 2016. How to Design Infrastructure Contracts in a Warming World: A critical appraisal of public-private partnerships. International Economic Review, 57(1), pp. 61-87. https://doi.org/10.1111/iere.12148

25. McKinsey Global Institute, 2016. Bridging Global Infrastructure Gaps. June.

26. Milbradt, G., 2016. History of the Constitutional Debt Limits in Germany and the New 'Debt Break: Experiences and critique in: E. Ahmad, M. Bordignon and G. Brosio, eds. Multi-level Finance and the Euro Crisis: Causes and Effects. Cheltenham: Edward Elgar, pp. 66-80. https://doi.org/10.4337/9781784715113

27. Sappington, D. E. M. and Stiglitz, J. E., 1987. Privatization, Information, and Incentives. Journal of Policy Analysis and Management, 6(4), pp. 567-582. https://doi.org/10.2307/3323510

28. Schmidt, K. M., 1996a. The Cost and Benefits of Privatization: An Incomplete Contracts Approach. Journal of Law, Economics, and Organization, 12(1), pp. 1-24. https://doi.org/10.1093/oxfordjournals.jleo.a023354 
29. Schmidt, K. M., 1996b. Incomplete Contracts and Privatization. European Economic Review, 40(3-5), pp. 569-579. https://doi.org/10.1016/0014-2921 (95)00070-4

30. Shapiro, C. and Willig, R. D., 1990. Economic Rationales for the Scope of Privatization in: E. N. Suleiman and J. Waterbury, eds. The Political Economy of Public Sector Reform and Privatization. San Francisco, CA: Westview Press.

31. Williamson, O., 1985. The Economic Institutions of Capitalism. New York: Free Press.

32. World Bank, International Evaluation Group, 2016. How to Assess the Capacity of a Government's FMIS as a Budget Management Tool. Washington, DC: The World Bank. 